\title{
Clinical experience in diagnosis and management of acquired methaemoglobinaemia: a case report and retrospective review
}

\author{
TT Chan ${ }^{1}$, MB, BS, MPH, William CY Leung ${ }^{2}$, MB, BS, CK Chan ${ }^{3}$, MB, BS FHAKM (Emergency Medicine), \\ Heinz KT Lo ${ }^{4}$, MB, BS, Winnie WY Tso ${ }^{5}$, MB, BS, FHKAM (Paediatrics), SH Tsui', MB, BS, FHKAM (Emergency Medicine), \\ Thomas SY Chan², FHKCP, FHKAM (Medicine), Richard SK Chang ${ }^{2}$ *, MB, BS, MRCP (HK) \\ ${ }^{1}$ Accident and Emergency Department, Queen Mary Hospital, Hong Kong \\ ${ }^{2}$ Department of Medicine, Queen Mary Hospital, Hong Kong \\ ${ }^{3}$ Clinical Toxicology Department, United Christian Hospital, Hong Kong \\ ${ }^{4}$ Department of Paediatrics, Kwong Wah Hospital, Hong Kong \\ ${ }^{5}$ Department of Paediatrics and Adolescent Medicine, The University of Hong Kong, Hong Kong \\ Hong Kong Med J 2021;27:366-9 \\ *Corresponding author: changsk@ha.org.hk \\ https://doi.org/10.12809/hkmj209028
}

\section{Case reports}

\section{Case 1}

In June 2008, a 9-month-old boy with unremarkable medical and developmental history presented to the emergency department with acute cyanosis. The child had been fed about $200 \mathrm{~g}$ of congee containing rice, vegetables, fish, and egg. He was then noted to have pallor of face and perioral cyanosis. He was conscious and irritable and reported to have vomiting. His respiratory rate was 40 breaths per minute and heart rate was 190 beats per minute. Pulse oximetry showed $90 \%$ oxygen saturation on $100 \%$ oxygen via a face mask. Physical examination was otherwise unremarkable. He was admitted to the paediatric intensive care unit. During blood sampling, his blood was noted to be chocolate brown. While on 100\% oxygen, his arterial blood gas showed a $\mathrm{pH}$ value of $7.33, \mathrm{PaO}_{2} 51.8 \mathrm{kPa}, \mathrm{PaCO}_{2} 4.2 \mathrm{kPa}$ and bicarbonate $17 \mathrm{mmol} / \mathrm{L}$. Blood methaemoglobin (MetHb) level was $51 \%$. He was treated with intravenous methylene blue $15 \mathrm{mg}$ (about $1.5 \mathrm{mg} / \mathrm{kg}$ ) and urine was observed to be light blue (Fig). His cyanosis resolved within 1 hour after treatment and

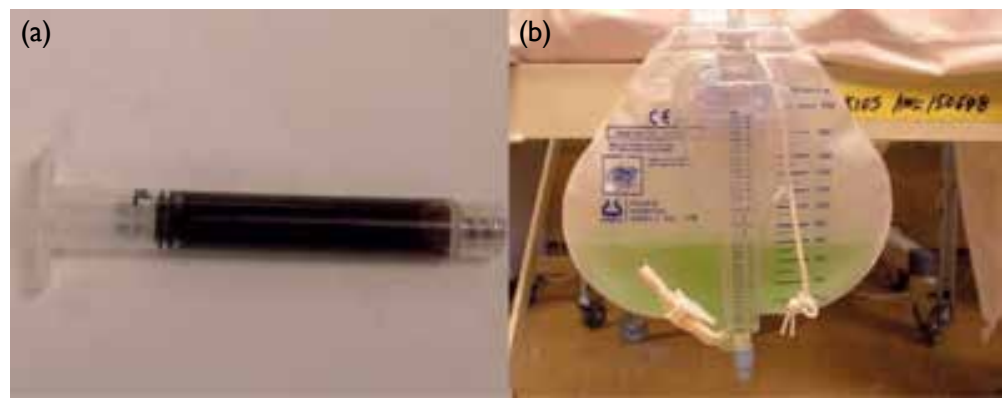

FIG. Case I: a 9-month-old boy with methaemoglobinaemia. (a) Chocolate brown blood taken after admission and (b) light blue urine after intravenous methylene blue treatment blood oxygen saturation returned to normal without oxygen supplementation. The MetHb level dropped to $1 \%$ within 30 minutes after treatment. Mutation screen of cytochrome B5 reductase gene (CYB5R3) was negative for the patient and both parents.

A high urinary nitrate level of $315 \mathrm{mg} / \mathrm{L}$ (reference range, 41.0-55.6 mg/L) was detected. Toxicology showed high nitrate and nitrite content in the congee consumed by the infant, $150 \mathrm{mg} / \mathrm{L}$ and $47.7 \mathrm{mg} / \mathrm{L}$, respectively. The uncooked vegetable Amaranthus remnant contained nitrate but at a safe level. Water used for cooking had come from a regular tap, not from a well that could otherwise have been a source of contamination.

The advised daily intake of nitrates and nitrites is 0 to $3.7 \mathrm{mg} / \mathrm{kg}$ and 0 to $0.07 \mathrm{mg} / \mathrm{kg}$ body weight, respectively. Our patient weighted $9.2 \mathrm{~kg}$ and his single-day consumption of nitrates and nitrites was $34 \mathrm{mg}$ and $0.644 \mathrm{mg}$, respectively. When he consumed $200 \mathrm{~g}$ of congee, he consumed $31.8 \mathrm{mg}$ of nitrates and $9.74 \mathrm{mg}$ of nitrites in one meal. The prescribed advised daily intake is for adults; a lower limit should apply for children. The patient has been followed up for 5 years with no recurrence of methaemoglobinaemia.

\section{Case 2}

In November 2018, a 50-year-old man with a history of schizophrenia was admitted following massive zopiclone overdose. He had taken more than 100 tabs of the hypnotic of $7.5 \mathrm{mg}$ each. There was no evidence of carbon monoxide inhalation. His presenting symptoms were dizziness, nausea, and reduced urine output. He was noted to be cyanotic and with oxygen saturation of $85 \%$ on $100 \%$ oxygen. During blood sampling, his blood was noted to be chocolate brown. Serum MetHb level was 40.3\% initially. Methylene blue $70 \mathrm{mg}$ (around $1 \mathrm{mg} / \mathrm{kg}$ ) as a slow intravenous bolus was administered in the 
emergency department and 1 hour later serum MetHb level had fallen to $19.3 \%$. Carboxyhaemoglobin was $3.8 \%$. He was admitted to the adult intensive care unit and received a further dose of intravenous methylene blue $70 \mathrm{mg}$. His saturation improved to $96 \%$ on pulse oximetry on oxygen supplementation at 1 litre per minute. Repeat measurement of MetHb showed it to be $<0.1 \%$. Carboxyhaemoglobin level peaked at $10 \%$ and gradually decreased. Urine was deep green in colour after methylene blue treatment. He also developed acute kidney injury (creatinine level peaked at $1239 \mu \mathrm{mol} / \mathrm{L}$ ) that required haemodialysis and a normochromic normocytic anaemia (trough haemoglobin level $6.2 \mathrm{~g} / \mathrm{dL}$ ). Haptoglobin level was low, indicative of haemolytic anaemia. Although evidence of oxidative haemolysis, such as Heinz bodies, was not documented on blood film examination, zopiclone-induced oxidative stress was probably the cause of haemolysis. Renal ultrasonography showed only mild renal parenchymal disease. His condition stabilised after an 11-day stay in the intensive care unit.

\section{Retrospective analysis}

To supplement the above cases, we searched through the computerised medical record system of our institution and identified all in-patients with International Classification of Diseases-9 code of 289.7, 'Methemoglobinemia', from January 2000 to December 2018. We identified 21 patients with acquired methaemoglobinaemia, aged 14 days to 67 years (Table). The most common cause was deliberate self-harm by overdosing with zopiclone. The most common clinical presentation was unexplained desaturation on pulse oximetry despite oxygen supplementation. Nine patients received methylene blue. One patient with coexisting glucose6-phosphate dehydrogenase (G6PD) deficiency was given ascorbic acid. Response to methylene blue was prompt in all cases, with MetHb falling to a nontoxic level soon after treatment.

\section{Discussion}

Infants or young children may be more susceptible to methaemoglobinaemia as the haemoglobin enzymes, such as cytochrome-b5 MetHB reductase, are immature. As in Case 1, nitrates in vegetables can cause methaemoglobinaemia, and this underlying cause is preventable. Nitrates are commonly found in agricultural products and well water, and can be formed by bacteria from nitrates. Home-prepared vegetables should be avoided in infants younger than 3 months of age. ${ }^{1}$ Farmers should avoid excessive use of nitrate-containing products during vegetable production, as suggested by agricultural guidelines. ${ }^{2}$ Well water should be monitored for nitrate contamination. Nitrate content can be converted to nitrite due to improper storage in a flask. Nitrate can also be reduced to nitrite by nitrate reductase intrinsic to plants or bacteria. Thus, proper washing, cooking and storage of food rich in nitrates is essential.

Medication is a main cause of acquired methaemoglobinaemia. Zopiclone overdose accounted for a significant portion in our series. As a non-benzodiazepine hypnotic, zopiclone is widely prescribed. Massive zopiclone overdose is relatively more common in Hong Kong because it can be obtained without a prescription. Intentional overdose has been reported in those attempting suicide. ${ }^{3}$ Zopiclone is known to be associated with methaemoglobinaemia especially following massive overdose, and with haemolytic anaemia and kidney injury. The elevated carboxyhaemoglobin in Case 2 was possibly endogenous due to haemolysis, as metabolism of haem via haem oxidase produces one molecule of CO per molecule of haem degraded. ${ }^{4}$

Other substances that can lead to methaemoglobinaemia include dapsone, nitrogen, and alanine. They induce oxidative stress in erythrocytes. In susceptible subjects who lack antioxidative enzymatic activity, the ferrous ion in the haem group is oxidised to a ferric state, forming $\mathrm{MetHb}$ that is incapable of binding oxygen. The oxygen dissociation curve is shifted to the left; oxygen desaturation, around $85 \%$, is common in methaemoglobinaemia. The underlying mechanism is related to the absorption of light wavelengths employed by emitter and detector of the pulse oximeter.

Clinical presentations of methaemoglobinaemia include both central and peripheral cyanosis, dizziness, headache, dyspnoea, and malaise. In extreme cases, coma or death may occur if MetHb exceeds $30 \%$ to $40 \%$. G6PD deficiency can exacerbate the methaemoglobinaemia and concomitant haemolysis. Vigilance is needed for clinical diagnosis. Unexplained cyanosis or poor oxygen saturation should prompt clinicians to consider methaemoglobinaemia. Medication and dietary histories, chemical contacts, recent medical or dental procedures and occupational exposure are conducive to diagnosis. Treatment mainly depends on the level of MetHb. For low levels, no specific treatment is needed. Methylene blue is usually indicated if MetHb exceeds $20 \%$. It acts as a cofactor to increase erythrocyte reduction of MetHb to haemoglobin in the presence of NADPH. Therapeutic response is usually prompt. In our series, MetHb level dropped in all cases to below 20\% after a single dose of methylene blue. Methylene blue should be used with caution in patients with G6PD deficiency as haemolysis can result from repeated use. An excessive cumulative dose of methylene blue can also potentially induce haemolysis. Ascorbic 
TABLE. Clinical features of patients with acquired methaemoglobinaemia

\begin{tabular}{|c|c|c|c|c|c|c|c|c|c|}
\hline Sex & Age & Presenting features & $\begin{array}{l}\text { MetHb on } \\
\text { presentation } \\
(\%)\end{array}$ & $\begin{array}{l}\text { Maximum } \\
\text { recorded } \\
\text { MetHb } \\
(\%)\end{array}$ & $\begin{array}{c}\text { G6PD } \\
\text { deficiency }\end{array}$ & Aetiology & Treatment & $\begin{array}{c}\text { MetHb } \\
\text { immediately } \\
\text { after } \\
\text { treatment } \\
(\%)\end{array}$ & Remarks \\
\hline M & $9 \mathrm{mo}$ & $\begin{array}{l}\text { Oxygen desaturation } \\
\text { upon pulse oximeter } \\
\text { monitoring; cyanosis }\end{array}$ & $51 \%$ & $51 \%$ & $\mathrm{~N}$ & $\begin{array}{l}\text { Nitrates/nitrites } \\
\text { from amaranth }\end{array}$ & $\mathrm{MB}, 15 \mathrm{mg}$ IV & $1 \%$ & Case 1 \\
\hline M & $50 \mathrm{y}$ & $\begin{array}{l}\text { Cyanosis and oxygen } \\
\text { desaturation upon pulse } \\
\text { oximeter monitoring }\end{array}$ & $40.3 \%$ & $40.3 \%$ & $\mathrm{~N}$ & Zopiclone OD & $\begin{array}{l}\text { MB, } 70 \text { mg IV } \\
\text { each, } 2 \text { doses }\end{array}$ & $19.3 \%$ & $\begin{array}{l}\text { Case } 2 \text { Concomitant } \\
\text { acute kidney injury } \\
\text { and anaemia }\end{array}$ \\
\hline M & $61 \mathrm{y}$ & Not documented & $3 \%$ & $3 \%$ & $\begin{array}{c}\text { Not } \\
\text { documented }\end{array}$ & Unknown & $\begin{array}{l}\mathrm{MB}, 50 \mathrm{mg} \\
\text { oral every } \\
\text { other day }\end{array}$ & NA & \\
\hline $\mathrm{F}$ & $60 \mathrm{y}$ & $\begin{array}{l}\text { Oxygen desaturation } \\
\text { upon pulse oximeter } \\
\text { monitoring }\end{array}$ & $4 \%$ & $13 \%$ & $\mathrm{~N}$ & Zopiclone OD & MB, 50 mg IV & $4 \%$ & \\
\hline M & $38 y$ & $\begin{array}{l}\text { Oxygen desaturation } \\
\text { upon pulse oximeter } \\
\text { monitoring; cyanosis }\end{array}$ & $41 \%$ & $41 \%$ & $\mathrm{~N}$ & Unknown & $\mathrm{MB}, 70 \mathrm{mg} \mathrm{IV}$ & 0 & \\
\hline M & $10 \mathrm{mo}$ & $\begin{array}{l}\text { Oxygen desaturation } \\
\text { upon pulse oximeter } \\
\text { monitoring }\end{array}$ & $6 \%$ & $6 \%$ & $\mathrm{Y}$ & Unknown & $\begin{array}{l}\text { Vitamin C, } \\
500 \text { mg oral }\end{array}$ & $4 \%$ & $\begin{array}{l}\text { Concomitant } \\
\text { haemolytic anaemia }\end{array}$ \\
\hline $\mathrm{F}$ & $34 \mathrm{y}$ & $\begin{array}{l}\text { Oxygen desaturation } \\
\text { upon pulse oximeter } \\
\text { monitoring }\end{array}$ & $8 \%$ & $8 \%$ & $\mathrm{~N}$ & Dapsone & Nil & NA & \\
\hline M & $14 \mathrm{~d}$ & $\begin{array}{l}\text { Oxygen desaturation } \\
\text { upon pulse oximeter } \\
\text { monitoring }\end{array}$ & $5 \%$ & $5 \%$ & $\begin{array}{c}\text { Not } \\
\text { documented }\end{array}$ & $\begin{array}{l}\text { Anaesthesia } \\
\text { with nitrous } \\
\text { oxide }\end{array}$ & $\begin{array}{l}\text { MB, dose not } \\
\text { documented }\end{array}$ & & \\
\hline M & $51 \mathrm{y}$ & $\begin{array}{l}\text { Oxygen desaturation } \\
\text { upon pulse oximeter } \\
\text { monitoring; cyanosis }\end{array}$ & $34 \%$ & $34 \%$ & $\mathrm{~N}$ & Zopiclone OD & $\begin{array}{l}\text { MB, dose not } \\
\text { documented }\end{array}$ & $81 \%$ & \\
\hline M & $45 y$ & Dyspnoea & $66 \%$ & $66 \%$ & $\mathrm{~N}$ & Aniline & MB, $70 \mathrm{mg} \mathrm{IV}$ & $2 \%$ & $\begin{array}{l}\text { Accidental } \\
\text { occupational aniline } \\
\text { exposure }\end{array}$ \\
\hline $\mathrm{F}$ & $29 y$ & Malaise & $21 \%$ & $21 \%$ & $\begin{array}{c}\text { Not } \\
\text { documented }\end{array}$ & Zopiclone OD & MB, $100 \mathrm{mg}$ IV & 0 & \\
\hline $\mathrm{F}$ & $52 y$ & $\begin{array}{l}\text { Oxygen desaturation } \\
\text { upon pulse oximeter } \\
\text { monitoring }\end{array}$ & $11 \%$ & $12 \%$ & $\mathrm{~N}$ & Dapsone & Nil & NA & \\
\hline$M$ & $54 \mathrm{y}$ & $\begin{array}{l}\text { Oxygen desaturation } \\
\text { upon pulse oximeter } \\
\text { monitoring }\end{array}$ & $6 \%$ & $15 \%$ & $\mathrm{Y}$ & $\begin{array}{l}\text { Herbal medicine } \\
\text { (suspected) }\end{array}$ & Nil & NA & \\
\hline M & $43 y$ & $\begin{array}{l}\text { Oxygen desaturation } \\
\text { upon pulse oximeter } \\
\text { monitoring }\end{array}$ & $2.1 \%$ & $2.1 \%$ & $\mathrm{~N}$ & Zopiclone OD & Nil & NA & \\
\hline $\mathrm{F}$ & $55 y$ & Asymptomatic & $1.2 \%$ & $1.2 \%$ & $\mathrm{~N}$ & Zopiclone OD & Nil & NA & \\
\hline M & $65 \mathrm{y}$ & $\begin{array}{l}\text { Oxygen desaturation } \\
\text { upon pulse oximeter } \\
\text { monitoring }\end{array}$ & $2.4 \%$ & $2.4 \%$ & $\mathrm{~N}$ & Zopiclone OD & Nil & NA & \\
\hline $\mathrm{F}$ & $53 y$ & $\begin{array}{l}\text { Oxygen desaturation } \\
\text { upon pulse oximeter } \\
\text { monitoring }\end{array}$ & $0.9 \%$ & $1.8 \%$ & $\mathrm{~N}$ & Zopiclone OD & Nil & NA & \\
\hline $\mathrm{F}$ & $29 y$ & $\begin{array}{l}\text { Oxygen desaturation } \\
\text { upon pulse oximeter } \\
\text { monitoring }\end{array}$ & $2.3 \%$ & $2.3 \%$ & $\mathrm{~N}$ & Zopiclone OD & Nil & NA & \\
\hline M & $16 y$ & $\begin{array}{l}\text { Oxygen desaturation } \\
\text { upon pulse oximeter } \\
\text { monitoring }\end{array}$ & $1.9 \%$ & $1.9 \%$ & $\mathrm{~N}$ & Zopiclone OD & Nil & NA & \\
\hline $\mathrm{F}$ & $35 y$ & Asymptomatic & $1 \%$ & $1 \%$ & $\mathrm{~N}$ & Zopiclone OD & Nil & NA & \\
\hline $\mathrm{F}$ & $67 y$ & $\begin{array}{l}\text { Oxygen desaturation } \\
\text { upon pulse oximeter } \\
\text { monitoring }\end{array}$ & $2 \%$ & $2 \%$ & $\mathrm{~N}$ & Zopiclone OD & Nil & NA & \\
\hline
\end{tabular}

Abbreviations: $\mathrm{F}=$ female; G6PD = glucose-6-phosphate dehydrogenase; $\mathrm{IV}=$ intravenous; $\mathrm{M}=$ male; $\mathrm{MB}=$ methylene blue; MetH $\mathrm{b}=$ methaemoglobin; $\mathrm{N}=$ no; $\mathrm{NA}=$ not available; $\mathrm{OD}=$ overdose; $Y$ = yes 
acid, an antioxidant, may be used as an alternative, either orally or intravenously. ${ }^{5}$ It works by scavenging free radicals and protects cells against oxidative stress, acting as a co-factor for NADP reductase and directly reducing $\mathrm{MetHb}$.

In conclusion, methaemoglobinaemia can affect a wide age range of patients and be due to a variety of agents. Effective treatment exists and the response is usually satisfactory.

\section{Author contributions}

Concept or design: All authors.

Acquisition of data: TT Chan, RSK Chang.

Analysis or interpretation of data: All authors.

Drafting of the manuscript: TT Chan, RSK Chang.

Critical revision for important intellectual content: All authors.

All authors had full access to the data, contributed to the study, approved the final version for publication, and take responsibility for its accuracy and integrity.

\section{Conflicts of interest}

The authors have no conflicts of interest to disclose.

\section{Funding/support}

This study received no specific grant from any funding agency in the public, commercial, or not-for-profit sectors.

\section{Ethics approval}

The patients were treated in accordance with the Declaration of Helsinki, and provided informed consent for all treatments and procedures. The retrospective analysis of patient data was approved by the University of Hong Kong/Hospital Authority Hong Kong West Cluster institutional review board (Ref UW 19-205) and the requirement for patient consent for publication was waived.

\section{References}

1. Greer FR, Shannon M, American Academy of Pediatrics Committee on Nutrition, American Academy of Pediatrics Committee on Environmental Health. Infant methemoglobinemia: the role of dietary nitrate in food and water. Pediatrics 2005;116:784-6.

2. European Commission. Encouraging low-input farming in the EU. Available from: https://ec.europa.eu/info/ food-farming-fisheries/sustainability/environmentalsustainability/low-input-farming. Accessed 8 Aug 2019.

3. Chan TY. Zopiclone induced methemoglobinemia and hemolytic anemia. Int J Clin Pharmacol Ther 2014;52:4026.

4. Hampson NB. Carboxyhemoglobin elevation due to hemolytic anemia. J Emerg Med 2007;33:17-9.

5. Lee KW, Park SY. High-dose vitamin C as treatment of methemoglobinemia. Am J Emerg Med 2014;32:936.

\section{Answers to CME Programme Hong Kong Medical Journal August 2021 issue}

Hong Kong Med J 2021;27:266-75

I. Utility of cardiac magnetic resonance imaging in troponin-positive chest pain with non-obstructive coronary arteries: literature review
A
1. False
2. True
3. True
4. False
5. False
B
1. False
2. True
3. False
4. True
5. True

Hong Kong Med J 2021;27:276-86

II. Initial intravenous fluid prescription in general paediatric in-patients aged $>28$ days and $<18$ years: consensus statements
A
1. True
2. True
3. False
4. True
5. False
B
1. True
2. False
3. False
4. True
5. True 